Periods,' 'Pliocene Beds,' 'Pleistocene Accumulations,' 'The Steppe Period,' etc.

The abysmal origin of the black shales of the Ordovician, with graptolites, is defended on the following grounds: The persistence of lithological characters over wide areas; their replacement by much greater thickness of normal sediments along ancient coast lines; the frequent occurrence together of blind trilobites and those with abnormally large eyes, and the interstratification of the black shales with radiolarian cherts similar to the modern abysmal radiolarian oozes.

The glacial origin of the boulder beds of the Talchin stage of the Indian series, proposed by W. T. Blanford, is accepted; and confirmatory evidence is cited in the cases of the similar signs of glaciation in beds of a corresponding age in Australia, South Africa and southern Brazil.

As a digest of the general facts of British geology in its special nomeclature the book will be of value to those who have not access to the fuller treatises.

Henry S. Willtams.

The Examination of Water (Chemical and Bacteriological). By William P. Mason. New York, John Wiley \& Sons. 1899. Pp. 135. The progress that has been made during the last decade in methods of sanitary water analysis, and especially in the interpretation of the results of such analysis, amply justifies an attempt at the marshalling of the new data and the revaluation of the old. To both students and practical workers the need of a really modern treatise in the English language has become imperative, and Professor Mason's little book will, on this ground, be cordially received. It will be a fact regretted by many, however, that the present work is so limited in scope. While the author correctly insists upon the paramount importance of a complete knowledge of the source of a sample of water and of the conditions under which the sample is collected, and rightly emphasizes the futility of 'standards' of purity, he has evidently not intended to include in this book any discussion of some of the other and most vital problems of water analysis.

The various methods for the determination of chlorine, nitrites, nitrates, free æmmonia, albuminoid ammonia, etc., and the other significant chemical tests are described in the second chapter, and the author's selection of recommended methods will, on the whole, meet with general approval. The useful 'normal chlorine' maps, prepared respectively by the Massachusetts and Connecticut State Boards of Health, are reproduced and the hope is expressed that the task of the water-analyst will, in the futurebe made still easier through the preparation of similar charts by other Commonwealths.

Some analysts will consider that more stress might have been profitably laid upon the Hehner method for the determination of 'perma, nent hardness,' especially in view of the fact that this method has been found greatly superior to the 'soap test' in dealing with the waters in some parts of the United States. In this chapter, too, it will occasion some surprise to find no reference whatever to the Kjeldahl method for determining organic nitrogen.

In the chapter upon bacteriological examination the author seems to be treading on less familiar ground than in the preceding section. In his description of the method of preparation of sugar bouillon the importance of the preliminary removal of muscle-sugar is overlooked, as is the fact that the indol test may be vitiated by the presence of muscle-sugar in -the broth. Miquel's method of examination and his theory of 'auto-infection' of waters are given a much more important place than would be accorded them by most bacteriologists. The author's statement on p. 117 that 'great cold is not fatal to germ-life' certainly needs some revision. EDWIN O. JoRdAN.

\section{A Monograph of the North American Potentilleae.} By Per Axel Rydberg. Memiors from the Department of Botany of Columbia University. Volume II. Issued November 25, 1898. 4to. Pp. 223. 112 plates.

Some years ago Dr. Per Axel Rydberg, a Scandinavian botanist educated in America, became interested in the group of the Rose Family which contains the Cinquefoils, and which have been known as the Potentilleae. Finding in the great collections of Columbia University (now transferred to the New York 
Botanical Garden) a rich mass of materials, he set himself to the task of making a complete monograph of the tribe, accompanying it with such a collection of plates as would throw as much light as possible upon the limits of genera and species understood by him. After nearly two years of delay the volume has appeared, and it is all that the friends of the author anticipated, and more too. It is a beautifully printed quarto volume of 223 pages and one hundred and twelve finely executed plates.

In discussing the relationship of the tribe Dr. Rydberg regards it as representing the lowest or primitive type of the family Rosaceae, and from it arose, as separate, divergent groups, the tribes Dryadeae, Rubeae and Sanguisorbeae, while from the latter arose the Roseae (with possible relationship to the Dryadeae). On the other hand, from Dryadeae arose the Cercocarpae and Spireae, and from the latter are derived by divergent development the families $\mathrm{Po-}$ meae, Drupaceae and Saxifragaceae. In regard to other relationships the author says: "It is evident that the Ranunculaceae and Rosaceae are very nearly related," and in his diagram showing the foregoing relationships places the Ranunculaceae immediately below the Potentilleae.

Thirteen genera are recognized in the Potentilleae, of which the largest is Potentilla with 107 species. The next in point of numbers is Horkelia with 47 species, followed by Fragaria with 20, and Drymocallis with 13 . Quite naturally, the author found it necessary to describe many new species, and occasionally to give a new name to an old species, because of the preoccupation of the old name. He has been rather conservative in this part of his work, for which he deserves our thanks. In Fragaria the new species are as follows: $F$. crinita, $F$. sibbaldifolia, $F$. truncata, $F$. platypetala, $F$. prolifica, $F$. pumila, $F$. terrae novae, $F$. pauciflora and $F$. firma. In the much larger genus, Potentilla, there are but nine new species, but this is due to the fact that Dr. Rydberg, in his work upon this genus, published many new species a couple of years ago in the Bulletin of the Torrey Botanical Club.

A most interesting table closes the text, giving data as to the distribution of the Potentilleae in North America. From this we learn that in California there are 64 species, in the Rocky
Mountains 61, in Oregon and Washington 53, Saskatchewan Region 29, Canadian Rocky Mountains 28, Texas and Arizona 27, the Great Plains 26, New England and Middle States 26, Great Basin 23, British Columbia 22, southern Mexico 19, Labrador and Baffin's Bay 17, the Prairie Region 17, Canada 16, Alaska 16, Greenland 15, Arctic Coast 12, Southern States 8, northern Mexico 8, Lower California 7, Central America 2.

This monograph must at once become authoritative for this group of plants, and to every working botanist dealing with the higher seedbearing plants it will be indispensable.

Charles E. Bessey.

The University of Nebraska.

SCIENTIFIC JOURNALS AND ARTICLES.

Terrestrial Magnetism and Atmospheric Electricity for March.-The promised series of portraits of eminent magneticians and electricians is begun in the present number with that of Professor Arthur W. Rücker, the President of the Permanent Committee on Terrestrial Magnetism and Atmospheric Electricity of the International Meteorological Conference. The journal has been enlarged to 72 pages, the present number being also freely illustrated and containing several important contributions by eminent investigators, as will appear from the table of contents:

Aimantation Induite par le Champ Terrestre sur les Aimants, E. Mascart.

Is there a 428. Day Period in Terrestrial Magnetism? J. F. Hayford.

Beobachtungen über die Eigenelectricität der Atmosphärischen Niederschläge, J. Elster and H. Geitel.

The Physical Decomposition of the Earth's Permamanent Magnetic Field-No. 1. The Assumed Normal Magnetization and the Characteristics of the Resulting Residual Field, L. A. Bauer.

Is the Principal Source of the Secular Variation of the Earth's Magnetism within or without the Earth's Crust? L. A. Bauer.

Tafeln zur Genäherten Auswertung von Kugelfunctionen und ihren Differentialquotienten, Ad. Schmidt (Gotha).

Erdmagnetische Beobachtungen im Umanaks-Fiord (Nordwest-Grönland), 1892-93, H. Stade.

Abstracts and Reviews.

Notes: Biographical Sketch of Professor Rücker. Activity in Magnetic Work. 